\title{
PROPAGATION PROTOCOL for Western Trilliums
}

SHEILA M KLEST

$A$ bout 7 species of the genus Trillium L. (Liliaceae) grow in the western US, of which 4 grow west of the Cascade Mountains in Oregon. Two species, Trillium ovatum Pursh (Pacific trillium) and $T$. rivale $S$. Wats (brook wakerobin) are pedicellate, belonging to the subgenus Trillium. The other 2 species, T. albidum J.D. Freeman (giant white wakerobin) and T. parviflorum Soukup (smallflower wakerobin), are sessile, belonging to subgenus Phyllantherum.

Trillium ovatum thrives in the mossy forest floor of the coniferous woods from sea level to about $1070 \mathrm{~m}$ $(3500 \mathrm{ft})$ elevation in the western Cascade Mountains. At my elevation $(230 \mathrm{~m}[750 \mathrm{ft}])$, T. ovatum blooms from late March through April and at higher elevations during May. It is pure, shining white with plain green leaves and sweetly fragrant.

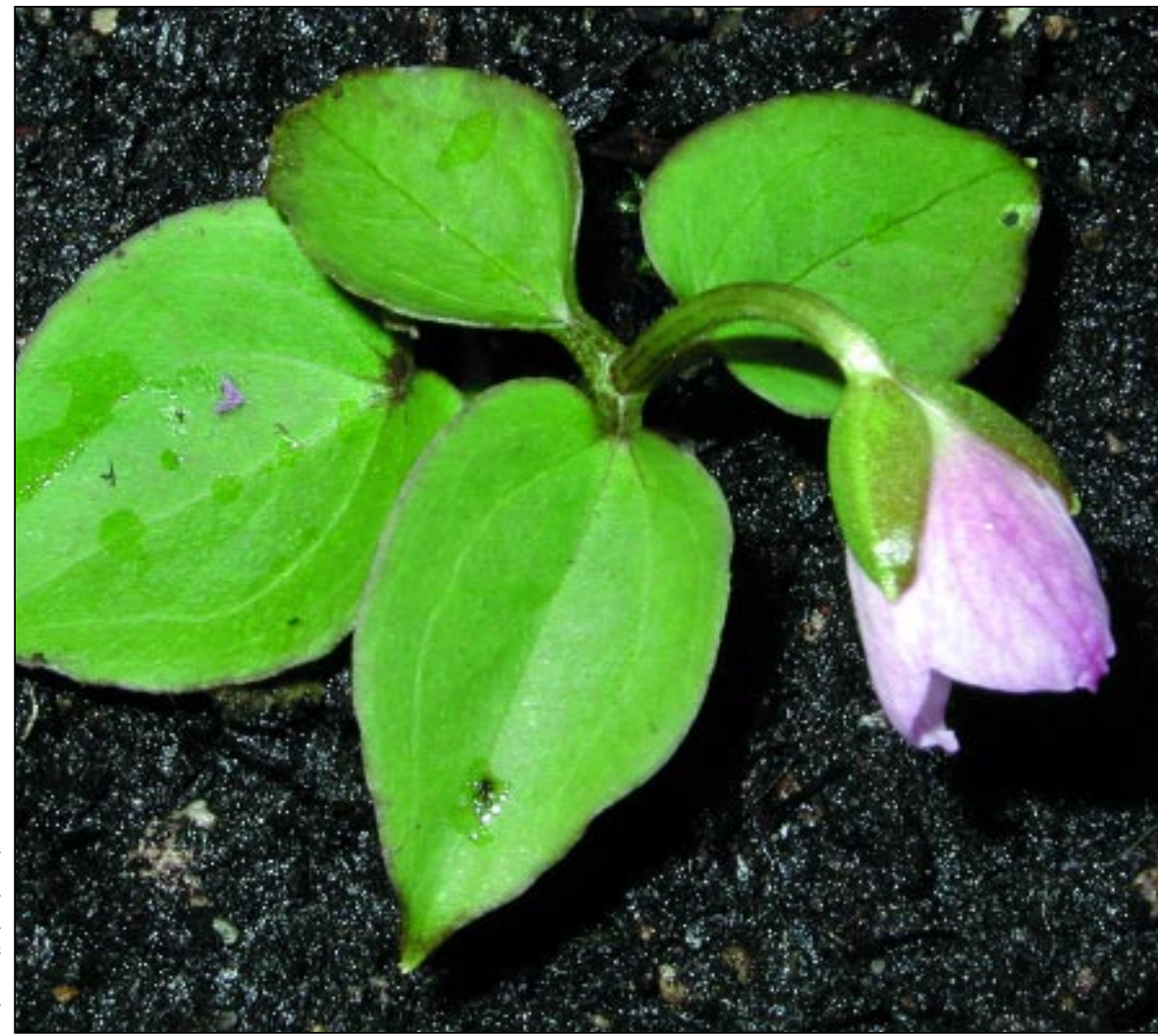

Figure 1 Brook wakerobin (T. rivale) in bloom.

Trillium rivale is endemic to the Siskiyou Mountains of southwestern Oregon. Small in stature (10 to $15 \mathrm{~cm} \mathrm{[4}$ to 6 in]), it grows in serpentine soils along small creeks, streams, and wet seepages. Despite its diminutive size, T. rivale is an exceptional plant having wide, white petals with purple spotting and a variable silver veining on bluish-green leaves. It blooms during March at my elevation and during May and June at higher elevations.

In my opinion, T. albidum is elegant and beautiful. This trillium has large, upright, white petals that persist from early March through April—the longest blooming period of the western trilliums. It is also extremely fragrant, similar to daphne (Thymelaeaceae). Trillium albidum often produces 2 or 3 stems from a single terminal bud. The leaves have dark mottling. In southern Oregon, it grows in riparian areas under cottonwoods (Populus spp. L. [Salicaceae]) and alders (Alnus spp. P. Mill. [Betulaceae]) and on wet banks leading to creeks.

Trillium parviflorum, as its name implies, has small flowers with narrow twisting petals that appear in late March through early April. More tolerant of wetter areas than $T$. ovatum, this trillium grows in very wet woods and along rivers at low elevations. The foliage is heavily mottled and most attractive.

\section{KEY WORDS:}

Trillium ovatum, Trillium rivale, Trillium albidum, Trillium parviflorum, Liliaceae, seed germination

\section{NOMENCLATURE:}

USDA NRCS (2001) 


\section{SEED COLLECTION AND GERMINATION}

I collect seeds from my own mature stock plants in early (the case with $T$. rivale) to late July when capsules are just about to split. I sometimes collect slightly under-ripe seeds, so as not to lose any seeds, and I haven't noticed any positive or negative effects on germination. Seeds are immediately sprinkled directly from capsules into a pot containing a mature plant or into 72 -cell plug trays $(4.2 \mathrm{X}$ 4.2 X $5.6 \mathrm{~cm}$ deep [1.7 X 1.7 X 2.25 in]; Land Mark Plastics Inc, Akron, Ohio) containing a 1:1 (v:v) mixture of sphagnum peat moss and perlite. Seeds are left uncovered.

Seeds in plug trays are watered daily throughout the summer and kept in a greenhouse with $80 \%$ shade cloth covering. In fall, I move them to an unheated shade house. In eastern trilliums, seeds generally produce a primary root the first spring after planting and a cotyledon the second spring after planting (Cullina 2002; Solt 2002).

However, the western trilliums are more precocious. The first spring after planting, $T$. rivale usually germinates at high rates $(90 \%$ to $100 \%)$ and cotyledons are visible by late February. Likewise, a very small percentage $(<15 \%)$ of T. ovatum, T. albidum, and T. parviflorum also germinate the first spring (February). Interestingly, T. ovatum seeds planted into pots containing mature plants always germinate and produce cotyledons the spring following planting. Regardless of whether cotyledons appear the first or second spring, plants in this stage receive 2 applications of Peters Professional PeatLite fertilizer $\left(15 \mathrm{~N}: 16 \mathrm{P}_{2} \mathrm{O}_{5}: 17 \mathrm{~K}_{2} \mathrm{O}\right.$; The Scotts Company, Marysville, Ohio) at about 180 ppm N (0.5 tbsp/gal). After true leaves emerge (second or third spring after planting), plants are watered with the same fertilizer and rate once every 2 or $3 \mathrm{wk}$.

\section{CULTURE}

The third or fourth spring after summer sowing, trilliums are potted into 3.7-1 (1-gal) containers filled with Rexius potting mix (a proprietary mixture of aged fine fir bark, compost, pumice, balanced fertilizer; $\mathrm{pH} 6.2$ to 6.5 ;

Rexius, Eugene, Oregon). Containers are top dressed with Apex controlledrelease fertilizer $\left(19 \mathrm{~N}: 8 \mathrm{P}_{2} \mathrm{O}_{5}: 12 \mathrm{~K}_{2} \mathrm{O} ; 10\right.$ to 12 mo release rate at $15.5^{\circ} \mathrm{C}\left[60{ }^{\circ} \mathrm{F}\right]$; Simplot Turf \& Horticulture, Lathrup, California) once each spring. Plants overwinter outside covered with Reemay fabric (Reemay Inc, Old Hickory, Tennessee) and white plastic. Trillium rivale will bloom about $5 \mathrm{y}$ after planting and the others in $7+y$.

\section{DANGERS}

It's a long and arduous road to becoming a blooming trillium. Here are some of the dangers faced:

1. Workers pulling up seedlings thinking they are weeds.

2. Sowbugs eating young plants.

3. Mosses, lichens, liverworts, and weeds covering the tops of containers.

4. Slugs-we have slugs, huge slugs, in Oregon. A single bite can eat through all 3 leaves and the flower when the plant is coming up in the spring or completely destroy a young plant.

5. Mice digging into pots and eating rhizomes during winter.

6. Viruses-I have had eastern T. grandiflorum (Michx.) Salisb. with mycoplasmas that spread to another eastern species (T. pusillum Michx.), however, I did not see it on our western trilliums. I sometimes find and discard T. albidum plants with twisted leaves.

\section{REFERENCES}

Cullina W. 2002. Propagation of North American trilliums. Native Plants Journal 3:14-17.

Solt S. 2002. Propagation protocol for Trillium L. (Liliaceae). Native Plants Journal 3:18-20.

USDA NRCS. 2001. The PLANTS database, Version 3.1. URL: http://plants.usda.gov (accessed $6 \mathrm{Mar}$ 2002). Baton Rouge (LA): National Plant Data Center.

\section{AUTHOR INFORMATION}

Sheila M Klest

Owner

Trillium Gardens

PO Box 803

Pleasant Hill, OR 97455

sheila@trilliumgardens.com

\section{Universityofldaho}

College of Natural Resources

\section{An integrated approach to understanding the ecology and management of ecosystems.}

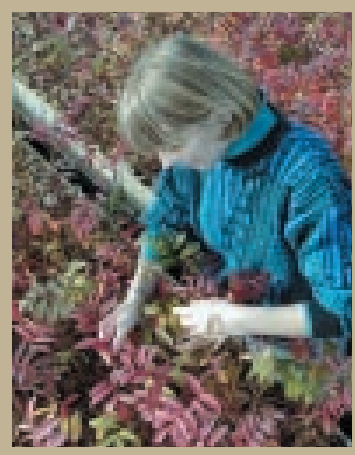

Undergraduate (BSc) and graduate (MSc and $\mathrm{PhD}$ ) degrees in:

- Ecology and Conservation Biology

- Fish and Wildlife Resources

- Forest Products

- Forest Resources

- Rangeland Ecology and Management

- Resource Recreation and Tourism

- Interdisciplinary Master of Natural Resources

Native plant research and production at the Forest Research Nursery

Web site: www.uidaho.edu/cnr E-mail:cnr@uidaho.edu College of Natural Resources, University of Idaho, Moscow, Idaho 83844-I I 30 208-885-7302

An AA/EO employer and educational institution 